\title{
THE OCCURRENCE OF GALLIUM IN MARINE ORGANISMS
}

\author{
By F. Culkin and J. P. Riley \\ The Department of Oceanography, The University, Liverpool
}

Little is known about the occurrence of gallium in the biosphere. The first recorded instance of its detection in a living organism is due to Cornec (1919), who detected the element in Laminaria sp. Vinogradov (1935) suspected its presence in an undetermined gorgonian, but his statement that Zvinden had detected it in human tissue appears to be an erroneous citation (Hutchinson, 1943). Bertrand (I94I) detected the element in oysters, and, after chemical concentration, in human urine.

Noddack \& Noddack (1940) have determined gallium spectrographically in nine marine organisms. They found concentrations (expressed as parts per million on the dry weight) ranging from O.I p.p.m. in Squalus acanthias to 0.7 p.p.m. in the body walls of Asterias rubens and Bryssopsis lyrifera. The average amount recorded ( $0 \cdot 4$ p.p.m.) corresponds to a concentration factor over sea water of 16,000 (assuming the gallium concentration of $0.025 \mu \mathrm{g} / \mathrm{l}$. in sea water, found by Burton, Culkin \& Riley, I958). The element has also been detected in Lycopodium flabelliforme (O.I p.p.m.) and Mitchella repens (0. I-0.2 p.p.m.) (Hutchinson \& Wollack, I943); in ambergris (Ishiguro, Koga \& Matsuo, 1952); in the outer layers of some seeds and fruits, and in several species of beetles (Bergman, Borovik \& Borovik-Romanova, I943; Borovik \& Borovik-Romanova, 1944, 1949). From these investigations the concentration of gallium in living organisms appears to be about $n \times \mathrm{IO}^{-5} \%$.

The biological role of gallium has been the subject of several investigations. Steinberg $(1938,1939 a, b$; 194I) has found that trace amounts of gallium are necessary for the growth of Aspergillus niger and Lemna minor in sterile medium. More recent investigations by Bertrand (1954) are, however, at variance with these conclusions. G. A. Riley (1943) has reported that in nutrient deficient culture the growth of the marine diatom, Nitzschia closterium $^{\star}$, is stimulated by gallium, but that this effect disappeared when nitrate and phosphate were present. No definite conclusions can be drawn from this study since no control experiments were made omitting gallium alone. Hewitt \& Bolle-Jones (1952) have found no evidence that gallium is an essential micronutrient for the growth of tomato, lettuce or sugar beet. Bardet, Levaditi, Tchakirian \& Vaisman (I93I) have studied the distribution of gallium in the organs of rabbits given gallium tartrate in their diet.

\footnotetext{
* i.e., Phaeodactylum tricornutum.
} 
In a review article on the biogeochemistry of aluminium and some other elements of Groups III $a$ and III $b$ of the Periodic Table, Hutchinson (I943) has pointed out that in many of its properties (gallous and gallic salts, complex cyanides) gallium shows a greater resemblance to iron than to aluminium. He concluded that it might play a part in metabolism similar to iron, but on a restricted scale. Gallium deficiencies are only likely to occur rarely, since few silicate rocks or soils contain less than 5 p.p.m. of the element.

Specific spectrophotometric methods for the determination of gallium in silicates and other minerals have been developed recently (Onishi \& Sandell, I955; Culkin \& Riley, I958). These procedures have sensitivities sufficiently high to allow the estimation of less than 0.I p.p.m. of gallium using samples weighing less than $5 \mathrm{~g}$. Using a modification of these methods, a study has been made of the distribution of the element in several marine organisms, derived mainly from the Irish Sea and the shores of the Isle of Man. In several of the samples the concentrations of iron, copper and aluminium have also been determined for comparison.

\section{METHODS}

\section{Reagents}

\section{Determination of gallium in marine organisms and shells}

(I) $7.5 \mathrm{~N}$ nitric acid.

(2) Perchloric acid, $60 \%(\mathrm{w} / \mathrm{w})$.

(3) Titanous chloride solution, $15 \%(\mathrm{w} / \mathrm{v})$.

(4) Di-iso-propyl ether. Freshly distilled from sodium hydroxide.

(5) Hydrochloric acid $(6.5 \mathrm{~N})$ containing I \% titanous chloride. Concentrated hydrochloric acid (s.G. I. $16,325 \mathrm{ml}$.) was mixed with $33 \mathrm{ml}$. of $15 \%$ titanous chloride solution and diluted to $500 \mathrm{ml}$.

(6) Rhodamine B solution. A solution was prepared containing $0.5 \mathrm{~g}$ of Rhodamine B in $100 \mathrm{ml}$. of water. The solution was filtered before use.

(7) Carbon tetrachloride-chlorobenzene solvent. Carbon tetrachloride (I25 ml.) was diluted to $500 \mathrm{ml}$. with chlorobenzene.

(8) Standard gallium solution $(5 \mu \mathrm{g} / \mathrm{ml}$.) was prepared by dissolving $0.0438 \mathrm{~g}$ of caesium gallium sulphate in water and diluting to $\mathrm{I} l$.

\section{Solution of samples of shells (carbonates)}

The weighed sample ( $5-10 \mathrm{~g}$ ) was placed in a $250 \mathrm{ml}$. conical flask and $50 \mathrm{ml}$. of $7.5 \mathrm{~N}$ nitric acid was gradually added. After effervescence had ceased, the flask was heated gently on a hot-plate for $30 \mathrm{~min}$, and the nitric acid was then evaporated. The residue was twice evaporated to dryness with 5-10 $\mathrm{ml}$. of hydrochloric acid, to remove the nitrate, and dissolved in $50 \mathrm{ml}$. of $6.5 \mathrm{~N}$ hydrochloric acid containing I $\%$ of titanous chloride.

\section{Solution of samples of marine organisms}

The weighed sample (up to $5 \mathrm{~g}$, dried at $110^{\circ} \mathrm{C}$ ) was placed in a $250 \mathrm{ml}$. conical flask, and $25 \mathrm{ml}$. of $7.5 \mathrm{~N}$ nitric acid was added. The flask was closed with a small funnel and its contents were allowed to digest in the cold until all foaming had 
ceased. The nitric acid was then removed by cautious evaporation on the hot plate. Repeated evaporations with $15 \mathrm{ml}$. portions of concentrated nitric acid were then carried out until all carbonaceous material was removed. The white or pale yellow residue was treated with $2 \mathrm{ml}$. of $60 \%(\mathrm{w} / \mathrm{w})$ perchloric acid and fumed to dryness. It was fumed to dryness again after addition of $2 \mathrm{ml}$. of concentrated sulphuric acid, and dissolved in $50 \mathrm{ml}$. of $6.5 \mathrm{~N}$ hydrochloric acid containing I \% of titanous chloride.

\section{Extraction of gallium}

The solution of the sample was transferred to a $250 \mathrm{ml}$. separating funnel, and, if it was not violet in colour, an excess of $15 \%$ titanous chloride was added. Two extractions with $30 \mathrm{ml}$. portions of di-iso-propyl ether were carried out and the combined extracts were evaporated in a beaker on the water bath.

\section{Photometric determination of gallium}

The residue in the beaker was dissolved by warming to $70-80^{\circ}$ with $5 \mathrm{ml}$. of $6.5 \mathrm{~N}$ hydrochloric acid containing I \% titanous chloride. The cold solution was transferred to a $50 \mathrm{ml}$. separating funnel containing $8 \mathrm{ml}$. of chlorobenzene-carbon tetrachloride solvent. The beaker was rinsed with a further I ml. of $6.5 \mathrm{~N}$ hydrochloric acid and the washings added to the funnel. Rhodamine B solution $(0.5 \mathrm{ml}$.) was added and the separating funnel was shaken mechanically for ro min. After the two phases had separated, the organic phase was run through a plug of glass wool into a $10 \mathrm{ml}$. calibrated flask containing I ml. of ethyl alcohol. The aqueous phase was washed with a further I ml. of the solvent and the washings added to the calibrated flask, which was then filled to the mark with the solvent. The optical density of the solution was measured at $562 \mathrm{~m} \mu$ in a $\mathrm{I} \mathrm{cm}$ cell. The reagent blank was determined in the same manner but omitting the sample. The method was calibrated using I, 2, 4, 6, 8 and Io $\mu \mathrm{g}$ of gallium. It was found that $5 \mu \mathrm{g}$ of gallium gave an optical density of 0.565 at $562 \mathrm{~m} \mu$ in a $\mathrm{I} \mathrm{cm}$ cell. Recoveries of gallium added to biological samples averaged $98 \%$.

\section{Determination of sulphated ash, iron, aluminium and copper}

The dried $\left(110^{\circ} \mathrm{C}\right)$ sample $(\mathrm{I} \mathrm{g})$ was weighed into a $25 \mathrm{ml}$. platinum crucible and allowed to stand for a few hours with ca. $5 \mathrm{ml}$. of concentrated nitric acid and $2 \mathrm{ml}$. of perchloric acid. The crucible was then carefully heated on a water bath until the nitric acid had evaporated. The evaporation with concentrated nitric acid was repeated until all organic matter had been destroyed. The perchloric acid was then fumed off under an infra-red heater, $2 \mathrm{ml}$. of concentrated sulphuric acid was added and the heating was continued until no further fumes were evolved. The contents of the crucible were treated with $2 \mathrm{~g}$ of powdered ammonium carbonate and heated at $40^{\circ} \mathrm{C}$. in a muffle furnace for $30 \mathrm{~min}$. The crucible was allowed to cool in the desiccator and weighed.

The sulphated ash was treated with $2 \mathrm{ml}$. of concentrated hydrochloric acid and I $5 \mathrm{ml}$. of water and heated on the water bath; the resultant solution was filtered into a $250 \mathrm{ml}$. graduated flask. The residue (if any) in the crucible was washed well with hot water and the washings added to the graduated flask. The solution was diluted to volume and used for the spectrophotometric estimation of iron and aluminium as described by Riley (1958), and for copper as described by Riley and Sinhaseni (1958). 


\section{OBSERVATIONS}

The composition of marine organisms

Gallium, aluminium, iron and copper have been determined in a number of marine plants and animals which were obtained mainly from the Irish Sea off Port Erin and Port St Mary. Unless otherwise stated the analyses were carried out on the whole organism, which had been washed thoroughly with distilled water and dried at $110^{\circ} \mathrm{C}$. In addition, the distribution of gallium and copper in certain organs of Buccinum undatum L., Chlamys opercularis (L.), Porania pulvillus (Müll.) and Pecten maximus (L.) has been studied. Specimens of Pecten maximus were analysed directly after removal from their habitat and also after being allowed to purge themselves in clean sea water for 7 days. The results of the analyses are shown in Tables I-6.

TABLE 1. OCCURRENCE OF GALLIUM, ALUMINIUM, IRON AND COPPER IN MARINE ALGAE

\begin{tabular}{|c|c|c|c|c|c|c|c|c|}
\hline Organism & $\begin{array}{l}\text { Ash } \\
(\%)\end{array}$ & $\underset{(\mu \mathrm{g} / \mathrm{g})}{\mathrm{Ga}}$ & $\underset{(\mu \mathrm{g} / \mathrm{g})}{\mathrm{Cu}}$ & $\underset{(\mu \mathrm{g} / \mathrm{g})}{\mathrm{Al}}$ & $\underset{(\mu \mathrm{g} / \mathrm{g})}{\mathrm{Fe}}$ & $\underset{\times \mathrm{IO}^{4}}{\mathrm{Ga} / \mathrm{Al}}$ & $\begin{array}{r}\mathrm{Ga} / \mathrm{Fe} \\
\times \mathrm{IO}^{4}\end{array}$ & $\begin{array}{c}\mathrm{Ga} \text { in } \\
\text { ash } \\
(\mu \mathrm{g} / \mathrm{g})\end{array}$ \\
\hline \multicolumn{9}{|l|}{ CHLOROPHYCEAE } \\
\hline $\begin{array}{l}\text { Codiaceae } \\
\text { Codium } \mathrm{sp} \text {. }\end{array}$ & $56 \cdot 2$ & 0.16 & 85.5 & I336 & 470 & $\mathrm{I} \cdot 2$ & 3.4 & 0.3 \\
\hline Halimeda gracilis & 123 & 0.05 & $22 \cdot 5$ & 143 & 342 & 3.5 & $\begin{array}{l}3.4 \\
1 \cdot 5\end{array}$ & 0.04 \\
\hline \multirow{2}{*}{\multicolumn{9}{|c|}{$\begin{array}{l}\text { PhaEOPHYCEAE } \\
\text { Fucaceae }\end{array}$}} \\
\hline & & & & & & & & \\
\hline Ascophyllum nodosum & $22 \cdot \mathrm{I}$ & 0.06 & $6 \cdot 2$ & 83.4 & $6 r \cdot 4$ & $7 \cdot 2$ & $9 \cdot 8$ & 0.3 \\
\hline Fucus serratus & 30.6 & 0.03 & $5 \cdot 6$ & IOI & 153.7 & 3.0 & $2 \cdot 0$ & 0.1 \\
\hline F. spiralis & $9 \cdot 2$ & 0.01 & 15.0 & $34: 4$ & 33.9 & $2 \cdot 9$ & $3 \cdot 0$ & $0 \cdot I$ \\
\hline F. vesiculosus & $24 \cdot 8$ & 0.03 & 18.0 & $5 \mathrm{I} \cdot 4$ & $36 \cdot 4$ & $5 \cdot 8$ & $8 \cdot 2$ & 0.1 \\
\hline Pelvetia canaliculata & $24 \cdot 2$ & 0.10 & 17.9 & 372 & 120.8 & $2 \cdot 7$ & $8 \cdot 2$ & 0.4 \\
\hline Laminariaceae & & & & & & & & \\
\hline Laminaria digitata & $37 \cdot 5$ & 0.07 & $6 \cdot 2$ & IOI & $40 \cdot 9$ & $7 \cdot 0$ & I7 & 0.2 \\
\hline \multicolumn{9}{|l|}{$\begin{array}{c}\text { RHODOPHYCEAE } \\
\text { Corallinaceae }\end{array}$} \\
\hline Corallina officinalis & II 4 & 0.56 & $44 \cdot 7$ & 4420 & 4680 & $I \cdot 3$ & $I \cdot 2$ & 0.5 \\
\hline Lithothamnion sp. & 113 & 0.53 & $15 \cdot 7$ & 3570 & 3420 & $\mathrm{I} \cdot 5$ & $\mathrm{I} \cdot 5$ & 0.5 \\
\hline $\begin{array}{l}\text { Lithophyllum sp. } \\
\text { Gigartinaceae }\end{array}$ & I2I & 0.23 & I $8 \cdot I$ & 243 & 374 & $\mathrm{I} \cdot \mathrm{O}$ & 0.6 & 0.2 \\
\hline $\begin{array}{l}\text { Gigartina stellata } \\
\text { Rhodomelaceae }\end{array}$ & I6.7 & 0.02 & $32 \cdot 8$ & $94 \cdot 8$ & 102 & $2 \cdot I$ & $2 \cdot 0$ & 0.1 \\
\hline $\begin{array}{l}\text { Polysiphonia lanosa } \\
\text { Rhodymeniaceae }\end{array}$ & $24 \cdot 9$ & 0.19 & $4 I$ & 478 & 493 & 4.0 & $2 \cdot 6$ & 0.8 \\
\hline Rhodymenia palmata & II 7 & 0.04 & $24 \cdot 4$ & I75 & 252 & $2 \cdot 3$ & $I \cdot 6$ & 0.03 \\
\hline
\end{tabular}

The range of gallium concentrations found for the various whole organisms was $0.0 \mathrm{I}-0.96$ p.p.m., which is in good agreement with the data for nine marine animals, published by Noddack \& Noddack (I940) (0.I-0.7 p.p.m.). Hutchinson (I943) has deduced from the Noddacks' results that gallium is concentrated biologically from sea water to a greater extent than aluminium. This conclusion must be reconsidered in the light of more recent determinations of both aluminium and gallium in sea water. Greenhalgh \& Riley (unpublished work) have found aluminium concentrations of $c a$. 10 $\mu \mathrm{g} / 1$. in the 
TABLE 2. OCCURRENCE OF GALLIUM, ALUMINIUM, IRON AND COPPER IN MARINE ANIMALS

\begin{tabular}{|c|c|c|c|c|c|c|c|c|}
\hline Organism & $\begin{array}{c}\text { Ash } \\
(\%)\end{array}$ & $\underset{(\mu \mathrm{g} / \mathrm{g})}{\mathrm{Ga}}$ & $\underset{(\mu \mathrm{g} / \mathrm{g})}{\mathrm{Cu}}$ & $\underset{(\mu \mathrm{g} / \mathrm{g})}{\mathrm{Al}}$ & $\underset{(\mu \mathrm{g} / \mathrm{g})}{\mathrm{Fe}}$ & $\underset{\times 10^{4}}{\mathrm{Ga} / \mathrm{Al}}$ & $\begin{array}{c}\mathrm{Ga} / \mathrm{Fe} \\
\times \mathrm{IO}^{4}\end{array}$ & $\begin{array}{l}\text { Ga in } \\
\text { ash } \\
(\mu \mathrm{g} / \mathrm{g})\end{array}$ \\
\hline $\begin{array}{l}\text { ProtozoA } \\
\text { Foraminifera }\end{array}$ & & & & & & & & \\
\hline Ramulina sp. & II 6 & $0 \cdot 18$ & III & 973 & I I 48 & $\mathrm{I} \cdot 9$ & $I \cdot 6$ & 0.2 \\
\hline $\begin{array}{l}\text { PORIFERA } \\
\quad \text { Halichondria panicea }\end{array}$ & $88 \cdot 7$ & 0.93 & 59.5 & 3700 & 4040 & $2 \cdot 5$ & $2 \cdot 3$ & $I \cdot I$ \\
\hline $\begin{array}{l}\text { COELENTERATA } \\
\text { Alcyonium digitatum } \\
\text { CRUSTACEA }\end{array}$ & $69 \cdot 0$ & 0.05 & $6 \mathrm{I} \cdot 5$ & 435 & $43^{8}$ & $I \cdot 2$ & $I \cdot I$ & $0 \cdot 1$ \\
\hline $\begin{array}{l}\text { Cirripedia } \\
\text { Balanus balanoides } \\
\text { Decapoda }\end{array}$ & 120 & 0.07 & $28 \cdot 7$ & 240 & 146 & $2 \cdot 9$ & $4 \cdot 8$ & 0.05 \\
\hline $\begin{array}{l}\text { Cancer pagurus } \\
\text { Corystes cassive- } \\
\text { launus }\end{array}$ & $\begin{array}{l}79 \cdot 0 \\
71 \cdot 6\end{array}$ & $\begin{array}{l}0.03 \\
0.36\end{array}$ & $35 \cdot 0$ & $\begin{array}{r}166 \\
1041\end{array}$ & $\begin{array}{r}157 \\
1045\end{array}$ & $\begin{array}{l}I \cdot 8 \\
3 \cdot 5\end{array}$ & $\begin{array}{l}I \cdot 9 \\
3 \cdot 4\end{array}$ & $\begin{array}{l}0.04 \\
0.5\end{array}$ \\
\hline $\begin{array}{l}\text { MoLLUSCA } \\
\text { (Shells only) } \\
\text { Lamellibranchia }\end{array}$ & & & & & & & & \\
\hline Mytilus edulis & - & 0.010 & $2 \cdot I$ & 38 & $4 \mathrm{I}$ & $2 \cdot 6$ & $2 \cdot 4$ & 0.01 \\
\hline Pecten maximus & - & 0.008 & $6 \cdot 0$ & $8 \mathrm{I}$ & II 8 & $\mathrm{I} \cdot \mathrm{O}$ & 0.7 & 0.01 \\
\hline $\begin{array}{l}\text { Chlamys opercularis } \\
\text { Gastropoda }\end{array}$ & - & 0.069 & $3 \cdot 8$ & I74 & 239 & $4 \cdot 0$ & $2 \cdot 8$ & 0.07 \\
\hline Buccinum undatum & - & 0.036 & $I \cdot 6$ & 76 & 85 & $4 \cdot 7$ & $4 \cdot 2$ & 0.04 \\
\hline Littorina littorea & - & O.OII & $5 \cdot 2$ & 32 & 45 & $3 \cdot 4$ & $2 \cdot 4$ & 0.01 \\
\hline Gibbula umbilicalis & - & 0.014 & $7 \cdot 9$ & 48 & $5 \mathrm{I}$ & $2 \cdot 9$ & $2 \cdot 7$ & 0.01 \\
\hline $\begin{array}{l}\text { MoLLuSCA } \\
\text { (Soft parts) } \\
\text { Lamellibranchia }\end{array}$ & & & & & & & & \\
\hline $\begin{array}{l}\text { Mytilus edulis } \\
\text { Pecten maximus }\end{array}$ & I5.8 & 0.16 & $53 \cdot 7$ & $\begin{array}{l}465 \\
\text { See } T\end{array}$ & $\begin{array}{l}325 \\
\text { ble VI. }\end{array}$ & 3.4 & $4 \cdot 9$ & $I \cdot 0$ \\
\hline $\begin{array}{l}\text { Chlamys opercularis } \\
\text { Gastropoda }\end{array}$ & I5.7 & 0.05 & $37 \cdot I$ & 186 & 1093 & $2 \cdot 7$ & 0.5 & 0.3 \\
\hline Buccinum undatum & $8 \cdot 8$ & 0.007 & 53.5 & I98 & 86 & 0.35 & 0.8 & 0.08 \\
\hline Littorina littorea & $12 \cdot 9$ & 0.06 & $50 \cdot 2$ & I98 & I7I & 3.0 & 3.5 & 0.5 \\
\hline L. littoralis & $9 \cdot 0$ & 0.05 & IO2 & 238 & 229 & $2 \cdot I$ & $2 \cdot 2$ & 0.5 \\
\hline Patella vulgata & $17 \cdot 7$ & 0.04 & - & 346 & 1415 & $I \cdot 2$ & 0.3 & 0.2 \\
\hline ECHINODERMATA & & & & & & & & \\
\hline Asteroidea & & & & & & & & \\
\hline Asterias rubens & $49 \cdot 2$ & $0 \cdot 10$ & $34 \cdot 7$ & I59 & 332 & $6 \cdot 3$ & $3 \cdot 0$ & 0.2 \\
\hline $\begin{array}{l}\text { Henricia sanguino- } \\
\text { lenta }\end{array}$ & $70 \cdot 5$ & 0.05 & $20 \cdot 4$ & 652 & 925 & 0.8 & 0.5 & 0.1 \\
\hline Luidia ciliaris & $42 \cdot 6$ & 0.03 & $59 \cdot 0$ & I52 & I49 & $2 \cdot 0$ & $2 \cdot 0$ & 0.1 \\
\hline $\begin{array}{l}\text { Marthasterias } \\
\text { glacialis }\end{array}$ & $64 \cdot 5$ & 0.02 & $37 \cdot 7$ & I42 & I86 & $\mathrm{I} \cdot 4$ & $I \cdot I$ & 0.03 \\
\hline Porania pulvillus & $65 \cdot 2$ & $0 \cdot 1 \mathrm{I}$ & $90 \cdot 0$ & 365 & 457 & 3.0 & $2 \cdot 4$ & 0.2 \\
\hline $\begin{array}{l}\text { Stichastrella rosea } \\
\text { Echinoidea }\end{array}$ & $88 \cdot 5$ & 0.10 & $35^{\circ} 0$ & 263 & 271 & $3 \cdot 8$ & $3 \cdot 7$ & $0 . I$ \\
\hline $\begin{array}{l}\text { Echinus esculentus } \\
\text { Spatangus purpureus }\end{array}$ & I I I & 0.03 & $76 \cdot 0$ & 597 & 597 & $5 \cdot 0$ & $5 \cdot 0$ & 0.03 \\
\hline $\begin{array}{l}\text { Whole organism } \\
\text { - gut }\end{array}$ & 122 & 0.35 & $36 \cdot 9$ & 1830 & I700 & $I \cdot 9$ & $2 \cdot I$ & 0.3 \\
\hline $\begin{array}{l}\text { Gut + contents } \\
\text { Ophiuroidea }\end{array}$ & I24 & $3 \cdot 7$ & $3 I \cdot 6$ & I6,480 & 14,800 & $2 \cdot 2$ & $2 \cdot 5$ & $3 \cdot 0$ \\
\hline Ophiocomina nigra & 105 & 0.09 & 29.5 & 894 & I 600 & $I \cdot O$ & 0.6 & 0.1 \\
\hline
\end{tabular}


TABLE 3. DISTRIBUTION OF GALLIUM, ALUMINIUM, IRON AND COPPER IN CHLAMYS OPERCULARIS

\begin{tabular}{|c|c|c|c|c|c|c|c|c|}
\hline Organ & $\begin{array}{l}\text { Ash } \\
(\%)\end{array}$ & $\underset{(\mu \mathrm{g} / \mathrm{g})}{\mathrm{Ga}}$ & $\underset{(\mu \mathrm{g} / \mathrm{g})}{\mathrm{Cu}}$ & $\underset{(\mu \mathrm{g} / \mathrm{g})}{\mathrm{Al}}$ & $\underset{(\mu \mathrm{g} / \mathrm{g})}{\mathrm{Fe}}$ & $\underset{\times \mathrm{IO}^{4}}{\mathrm{Ga} / \mathrm{Al}}$ & $\begin{array}{c}\mathrm{Ga} / \mathrm{Fe} \\
\times \mathrm{IO}^{4}\end{array}$ & $\begin{array}{c}\mathrm{Ga} \text { in } \\
\text { ash } \\
(\mu \mathrm{g} / \mathrm{g})\end{array}$ \\
\hline Shell & - & 0.07 & $3 \cdot 8$ & I74 & 239 & 4.0 & 2.9 & 0.07 \\
\hline Muscle & $6 \cdot 5$ & 0.06 & $47 \cdot 9$ & 773 & $52 \cdot 8$ & 0.8 & $I \cdot I$ & $I \cdot 0^{\prime}$ \\
\hline Gonad & 10.4 & 0.06 & - & - & - & - & - & 0.6 \\
\hline Mantle and viscera & $21 \cdot 6$ & 0.55 & II 50 & 3420 & 2720 & $I \cdot 6$ & $2 \cdot 0$ & $2 \cdot 5$ \\
\hline
\end{tabular}

TABLE 4. DISTRIBUTION OF GALLIUM AND COPPER IN BUCCINUM UNDATUM

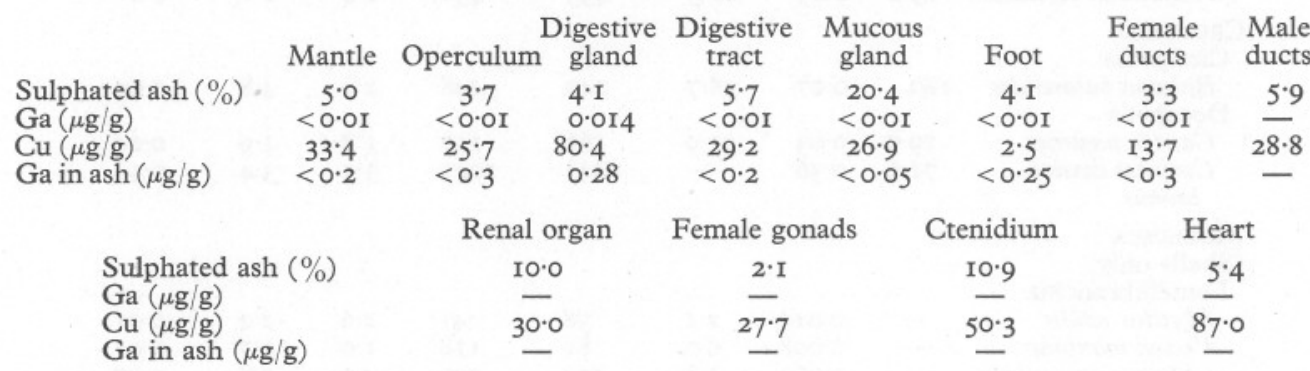

TABLE 5. DISTRIBUTION OF GALLIUM IN PORANIA PULVILLUS

$\begin{array}{lcccc} & \text { Skin } & \begin{array}{c}\text { Digestive } \\ \text { gland }\end{array} & \begin{array}{c}\text { Stomach }+ \text { oral } \\ \text { region }\end{array} & \begin{array}{c}\text { Skin from } \\ \text { aboral region }\end{array} \\ \text { Sulphated ash }(\%) & - & \mathrm{II} \cdot 3 & 95 & 60.4 \\ \mathrm{Ga}(\mu \mathrm{g} / \mathrm{g}) & 0.5 & 0.02 & 0.20 & 0.09 \\ \mathrm{Ga} \mathrm{in} \mathrm{ash}(\mu \mathrm{g} / \mathrm{g}) & - & 0.18 & 0.2 \mathrm{I} & 0.15\end{array}$

TABLE 6. DISTRIBUTION OF GALLIUM, ALUMINIUM, IRON AND COPPER IN PECTEN MAXIMUS

\begin{tabular}{|c|c|c|c|c|c|c|c|c|}
\hline Unpurged & $\begin{array}{c}\text { Full } \\
\text { gonad }\end{array}$ & $\begin{array}{l}\text { Spent } \\
\text { gonad }\end{array}$ & $\begin{array}{l}\text { Striped } \\
\text { muscle }\end{array}$ & $\begin{array}{l}\text { Unstriped } \\
\text { muscle }\end{array}$ & Mantle & $\begin{array}{l}\text { Digestive } \\
\text { gland }\end{array}$ & $\underset{\text { gut }}{\text { Gonad }}$ & $\begin{array}{c}\text { Mantle+ } \\
\text { gut }+ \text { di- } \\
\text { gestive } \\
\text { gland }\end{array}$ \\
\hline Sulphated ash (\%) & 10.7 & $3 \cdot 2$ & $6 \cdot 0$ & $4 \cdot 7$ & 13.3 & $7 \cdot 2$ & $12 \cdot 6$ & 13.9 \\
\hline $\mathrm{Ga}(\mu \mathrm{g} / \mathrm{g})$ & $<0.01$ & 0.009 & $<0.01$ & $<0.01$ & $<0.01$ & 0.79 & 0.29 & 0.30 \\
\hline $\mathrm{Al}(\mu \mathrm{g} / \mathrm{g})$ & - & - & $86 \cdot 6$ & - & I6I & 454 & 833 & 842 \\
\hline $\mathrm{Fe} \mu \mathrm{g} / \mathrm{g})$ & - & - & I67 & - & 189 & $84 \mathrm{I}$ & 1552 & 766 \\
\hline $\mathrm{Cu}(\mu \mathrm{g} / \mathrm{g})$ & - & $25 \cdot 2$ & 4.0 & - & - & I53 & - & $50 \cdot 8$ \\
\hline $\mathrm{Ga}$ in $\operatorname{ash}(\mu \mathrm{g} / \mathrm{g})$ & $<0.1$ & 0.28 & $<0.2$ & $<0.2$ & $<0 . I$ & II.O & $2 \cdot 3$ & $2 \cdot 2$ \\
\hline Purged & & Gills & $\begin{array}{r}\text { Male } \\
\text { gonad }\end{array}$ & $\begin{array}{c}\text { Female } \\
\text { gonad }\end{array}$ & $\begin{array}{l}\text { Str } \\
\text { mu }\end{array}$ & $\begin{array}{r}\mathrm{G} \\
\text { gesti }\end{array}$ & $\begin{array}{l}\text { ut + di- } \\
\text { ive gland }\end{array}$ & Mantle \\
\hline Sulphated ash (\%) & & 25.0 & $3 \cdot 0$ & 10.2 & & $\cdot 7$ & 10.9 & $9 \cdot 4$ \\
\hline $\mathrm{Ga}(\mu \mathrm{g} / \mathrm{g})$ & & 0.14 & 0.034 & $<0.01$ & & D.OI & O.OII & 0.01 \\
\hline $\mathrm{Cu}(\mu \mathrm{g} / \mathrm{g})$ & & $6 \cdot 3$ & II 3 & $26 \cdot 6$ & & $7 \cdot 5$ & $70 \cdot 9$ & $10 \cdot 2$ \\
\hline $\mathrm{Ga}$ in $\operatorname{ash}(\mu \mathrm{g} / \mathrm{g})$ & & 0.56 & $I \cdot I$ & $<0 . I$ & & & $I \cdot 0$ & $<0.1$ \\
\hline
\end{tabular}


Irish Sea and English Channel; Monaghan, Simons \& Taggert (I953) have detected similar amounts in the Atlantic Ocean and in the waters of the Gulf of Mexico. These amounts are approximately two orders of magnitude less than earlier work had indicated (cf. Richards, I957). Assuming an aluminium content of $10 \mu \mathrm{g} / 1$. and a gallium content of $0.025 \mu \mathrm{g} / 1$. (Burton, Culkin \& Riley, I958), the $\mathrm{Ga}: \mathrm{Al}$ ratio in sea water is $25 \times 10^{-4}$. The average $\mathrm{Ga}: \mathrm{Al}$ ratio in the lithosphere is $c a .2 \times 10^{-4}$, which shows that sea water is enriched approximately tenfold in gallium relative to aluminium compared with the lithosphere.

The average value of the $\mathrm{Ga}: \mathrm{Al}$ ratio for the marine organisms examined in this paper was $2-3 \times 10^{-4}$, which is very similar to the average ratio for the lithosphere $\left(c a .2 \times \mathrm{IO}^{-4}\right)$. Since the majority of the specimens examined were either bottom-living or from shallow water it seems very probable that most of their aluminium and gallium was derived from the bottom muds rather than from the sea water itself. The actual range found for the Ga:Al ratio is small $\left(\mathrm{I}-7 \times \mathrm{IO}^{-4}\right)$. This suggests that there is no significant biological separation of gallium from aluminium in the specimens examined, if allowance is made for variations in the $\mathrm{Ga}$ and $\mathrm{Al}$ contents of the muds in the various localities in which they lived.

The iron content of the organisms is generally similar to their aluminium content, but the $\mathrm{Ga}: \mathrm{Fe}$ ratio shows rather greater variations than the $\mathrm{Ga}: \mathrm{Al}$ ratio. The variation in the iron concentration is probably related to its role as an essential trace element in biological systems.

There is apparently no relationship between species and their contents of gallium, iron, aluminium or copper. The low concentrations of these elements found in the calcareous shells of molluscs suggests that the mechanism by which the calcium of sea water is converted into calcium carbonate is quite selective for calcium. The gallium contents of the shells are similar to those of carbonate rocks (Culkin \& Riley, unpublished). All four elements are concentrated in the digestive glands and viscera of the molluscs, but it seems probable that the gallium, aluminium and iron contents of these organisms are associated with ingested detritus. This is confirmed by the low concentrations of these elements present in the gut and digestive glands of Pecten maximus specimens, which had been allowed to purge themselves in filtered sea water for 7 days. The copper contents of the purged and unpurged specimens were similar, and it is probable that the copper in them is mainly adsorbed on to the mucous surfaces.

The authors thank Mr D. J. Slinn for supplying, identifying and dissecting the marine organisms. 


\section{SUMMARY}

A spectrophotometric method has been developed for the determination of submicrogram amounts of gallium in biological materials. Using this procedure a study has been made of the occurrence of gallium in a number of marine plants and animals (dried at $110^{\circ} \mathrm{C}$ ). Data are also presented for the concentrations of iron, aluminium and copper in the same samples.

The gallium content of the samples ranged from $c a$. 0.01 to 0.96 p.p.m. The Ga: Al ratio varied from $\mathrm{I}-7 \times 10^{-4}$ (average $2-3 \times 10^{-4}$ ), which compares well with the average $\mathrm{Ga}: \mathrm{Al}$ ratio of the lithosphere, and contrasts with the ratio of $25 \times 10^{-4}$ for sea water. It seems likely that the organisms examined derived their gallium, aluminium and iron from the bottom muds rather than from the sea water. There is no evidence of selective uptake of gallium in preference to aluminium. Iron and aluminium were generally present in roughly equal amounts.

The distribution of gallium in the various organs of Pecten maximus, Buccinum undatum, Chlamys opercularis and Porania pulvillus, has been investigated. Most of the tissues of these molluscs contain less than 0.07 p.p.m. of gallium, but the viscera and digestive organs contain higher concentrations, presumably contained in ingested inorganic material. The average gallium content of carbonate shells is 0.02 p.p.m.

\section{REFERENCES}

Bardet, J., LeVaditi, C., Tchakirian, A. \& Vaisman, A., I93i. La répartition du gallium dans l'organisme. C.R. Acad. Sci., Paris, T. 193, pp. I17-19.

Bertrand, D., I94I. Microrecherche du gallium. Bull. Soc. Chim., Paris., Sér. 4, T. 8 , pp. $58 \mathrm{I}-3$.

— I954. Le gallium peut il être considéré comme un oligo-élément indispensable pour l'Aspergillus niger? C.R. Acad. Sci., Paris., T. 239, pp. 1704-6.

Bergman, G. G., Borovik, S. A. \& Borovik-Romanova, T. F., I943. Trace elements contained in kok-saghyz. C.R. Acad. Sci. U.R.S.S., Vol. 40, pp. 329-30.

Borovik, S. A. \& Borovik-Romanova, T. F., I944. Determination of microelements in different parts of fruits and seeds. Trav. Lab. Biogéochim. U.R.S.S., Vol. 7, pp. III-I3.

Borovik, S. A. \& Borovik-Romanova, T. F., I949. Content of rare elements in insects from data of spectrum analysis. Trudy biogeokhim. Lab. Akad. Nauk, S.S.S.R., No. 9, pp. 149-54.

Burton, J. D., Culkin, F. \& Riley, J. P., I958. Germanium and gallium in sea water. Nature, Lond., Vol. 181, pp. 179-80.

CorneC, E., r9I9. Étude spectrographique des cendres de plantes marines. C.R. Acad. Sci., Paris., T. 168, pp. 513-I4.

Culkin, F. \& Riley, J. P., I958. The spectrophotometric determination of gallium in rocks and minerals. Analyst, Vol. 83, pp. 208-I2.

Hewitt, E. J. \& Bolle-Jones, E. W., 1952. Possible micro-nutrient elements for higher plants. I. Experiments with cobalt, nickel and gallium in seed culture. Ann. Rep. Agric. Hort. Res. Stn, Long Ashton, Bristol, year 1951, pp. 62-6. 
Hutchinson, G. E., I943. The biogeochemistry of aluminium and of certain related elements. Quart. Rev. Biol., Vol. I8, pp. 260-I.

Hutchinson, G. E. \& Wollack, A., I943. Biological accumulators of aluminium. Trans. Conn. Acad. Arts Sci., Vol. 35, pp. 73-I28.

Ishiguro, T., Koga, N. \& Matsuo, Y., I952. Constituents of ambergris. II. Inorganic constituents of ambergris. F. pharm. Soc. Fapan, Vol. 72, pp. 1439-43.

Monaghan, P. H., Simons, L. H. \& TAGgerT, M. S., I953. Aluminium and iron in Atlantic and Gulf of Mexico waters. Anal. Chem., Vol. 25, pp. 989-9o.

NoDdAcK, I. \& NodDACK, W. 1940. Die Häufigkeiten der Schwermetalle im Meerestieren. Ark. Zool., Bd. 32, pp. I-35.

Onishi, H. \& SANDell, E. B. I955. Photometric determination of gallium with Rhodamine B. Analyt. chim. acta., Vol. 13, pp. 159-64.

Richards, F. A., 1957. Physics and Chemistry of the Earth, Vol. 2, pp. 77-I29. Pergamon Press.

RILeY, G. A., I943. Physiological aspects of spring diatom flowering. Bull. Bingham oceanogr. Coll., Vol. 8, art. 4.

RILEY, J. P., I958. The rapid analysis of silicate rocks and minerals. Analyt. chim. acta. (In the Press.)

RiLEy, J. P., \& Sinhaseni, P., I958. The determination of copper in sea-water, silicate rocks and biological materials. Analyst, Vol. 83, pp. 299-304.

STEINBERG, R. A., I938. The essentiality of gallium to growth and reproduction of Aspergillus niger. F. Agric. Res., Vol. 57, pp. 569-74.

- I939a. Effects of nitrogen compounds and trace elements on growth of Aspergillus niger. F. agric. Res., Vol. 59, pp. 731-8.

- I $1939 b$. Relations of carbon nutrition to trace element and accessory requirements of Aspergillus niger. F. Agric. Res., Vol. 59, pp. 749-63.

- I94I. Use of Lemna for nutrition studies on green plants. F. agric. Res., Vol. 62, pp. 423-30.

VINOGRADOv, A., I935. The elementary chemical composition of marine organisms. Part I. Trav. Lab. biogeochim. U.R.S.S., Vol. 3, pp. 67-278. 